\title{
Comparison of rail and road transportation costs for general cargo distribution in Mexico
}

\section{Comparativo de costos de transporte férreo y carretero para la distribución de carga en general en México}

\author{
QUINTERO-RAMIREZ, Juan Manuel $\dagger^{* 1}$, OMAÑA-SILVESTRE, José Miguel² and BLAS-CORTES, \\ Jonatan $^{3}$ \\ ${ }^{I}$ Cátedra CONACyT Ciudad de México, México. \\ ${ }^{2}$ Profesor Investigador Titular. Colegio de Posgraduados, Campus Montecillo, Texcoco, Estado de México, México. \\ ${ }^{3}$ Posdoctorante. Colegio de Posgraduados, Campus Montecillo, Texcoco, Estado de México, México. \\ ID $1^{\text {st }}$ Author: Juan Manuel, Quintero-Ramírez / ORC ID: 0000-0002-1040-2690, CVU CONACYTT ID: 292056 \\ ID $1^{\text {st }}$ Co-author: José Miguel, Omaña-Silvestre / ORC ID: 0000-0002-5356-549X, CVU CONACYT ID: 59890 \\ ID $2^{\text {nd }}$ Co-author: Jonatan, Blas-Cortés / ORC ID: 0000-0001-5357-6968, CVU CONACYT ID: 325455
}

DOI: $10.35429 / J B S .2021 .19 .7 .51 .59$

Received March 21, 2021; Accepted June 30, 2021

\begin{abstract}
Mexico has an extension of railways that has not presented great variations through time. In spite of this, it does not lose importance in comparison with highways that have been increasing their construction and modernization. Therefore, the objective of the present investigation is to analyze the costs of rail and road land transportation as a proposal that optimizes the distribution of cargo merchandise in general in Mexico. This research is broken down into: the identification and selection of general cargo transportation routes to gather information on distances, time, transportation costs; the calculation of rail and road transportation costs of the selected routes as a comparative for decision making in the mobilization of merchandise; and finally the processing and modeling of the information that allows minimizing the costs of the routes in the mobilization of general cargo merchandise in the transportation types. The analysis carried out allowed to conclude that great efforts have been made focused on developing and increasing competitiveness in the railway system in Mexico, but it has not been able to strengthen itself as the most used mean of cargo transporting, even though, the rail transportation cost are lower than motor transportation for a same route.
\end{abstract}

Rail transport, Road transport, Transportation costs

\begin{abstract}
Resumen
México cuenta con una extensión de vías férreas que no ha presentado grandes variaciones a través del tiempo. A pesar de esto, no pierde importancia en comparación con las carreteras que han ido incrementando su construcción y modernización. Por lo tanto, el objetivo de la presente investigación es analizar los costos del transporte terrestre ferroviario y carretero como una propuesta que optimice la distribución de mercancías de carga en general en México. Esta investigación se desglosa en: la identificación y selección de rutas de transporte de carga en general para recabar información sobre distancias, tiempos, costos de transporte; el cálculo de los costos de transporte ferroviario y carretero de las rutas seleccionadas como un comparativo para la toma de decisiones en la movilización de mercancías; y finalmente el procesamiento y modelación de la información que permita minimizar los costos de las rutas en la movilización de mercancías de carga en general en los tipos de transporte. El análisis realizado permitió concluir que se han realizado grandes esfuerzos enfocados a desarrollar e incrementar la competitividad del sistema ferroviario en México, pero no ha logrado fortalecerse como el medio de transporte de carga más utilizado, a pesar de que los costos de transporte ferroviario son menores que los del autotransporte para una misma ruta.
\end{abstract}

Transporte ferroviario, Transporte carretero, Costos de transporte

Citation: QUINTERO-RAMIREZ, Juan Manuel, OMAÑA-SILVESTRE, José Miguel and BLAS-CORTES, Jonatan. Comparison of rail and road transportation costs for general cargo distribution in Mexico. Journal of Business and SMEs. 2021. 7-19: 51-59

\footnotetext{
*Correspondence to Author (e-mail: quintauro82@gmail.com)

$\dagger$ Researcher contributing first author.
} 


\section{Introduction}

Logistics is a crucial tool to achieve the growth of the company, mainly of any company that intends to join the dynamics of international trade, in other words, the growing demands of the market have driven the development of logistics models and processes that become elements of competitiveness for the company, being then the logistics an activity that increases the added value of companies and allows them to enter highly competitive markets, where delivery times are extremely strict. In Mexico as of the 20th century, there were 13,615 kilometers of railroad tracks; in 1900 alone, more than one thousand kilometers of tracks were laid, and by 1910 there was already an infrastructure of 19,280 kilometers of tracks (Medina, 2013).

According to figures from the World Trade Organization (WTO, 2014), world trade has been growing steadily in relation to world production over the last three decades, and has been linked to global value chains. By 2013, it was the second continuous year that international trade grew less than gross domestic product, marking a temporary break in the trend in recent years. The transportation used in Mexico is preferred in all its parts by the terrestrial modality as a commercial part in its distribution. Freight transportation or better known as road transportation is the most used, both nationally and for neighboring foreign trade, since costs are low and it has easy access to the cargo areas of goods, thus leaving the preference of companies to send their cargo by this means of transportation. An example of this is that in 2013 it transported $56 \%$ of exports and $51 \%$ of imports by road (INEGI, 2015).

Another important means of cargo transportation is the railroad, since it allows distributing and transporting large loads, which among them are raw materials, food, clothing, bringing a great economic benefit that allows the country to grow daily (Medina, 2013). The participation of the railroad is focused on transporting large volumes of cargo and initiating its shipment towards a direction and changing if required, as long as the direction of the new destination ensures that the machine continues forward and does not go backwards.
In that sense the importance of the railroad for the economic strength and social unity of a country is unquestionable (Ferrocarriles Nacionales Mexicanos, 2011). As Naumann (2004) mentions, "There is a record of a wide lack of coordination among the different operators, which makes it difficult to provide the service, a situation that adds to the lack of an adequate infrastructure for loading and unloading goods from the railroads, known as 'last mile', so that companies wishing to use the railroad may end up incurring higher costs compared to those of motor transport".

Currently, the function of transportation networks is to connect the existing logistic nodes in a given territory, the purpose of this connection is to facilitate the operation of marketing and distributing goods and services at national and international levels. In Mexico, road transportation has a high cost, which means that the price of transporting goods has an impact on their final price.

The aforementioned is a consequence of the fact that in Mexico there is a limited network of routes for the circulation of goods, another important aspect to point out is that there are few exits in the route networks, likewise, there is little knowledge of alternative transportation routes, and there is also a lack of security, mainly on the highways, as a consequence of the economic and social environment in the country.

Consequently, Mexico's transportation infrastructure, such as roads, ports, airports and railroads, is underdeveloped, as mentioned in the Logistics Performance Index of the World Bank, Mexico ranks 56th in terms of infrastructure (LPI, 2020). Together, the transportation network for the transportation of cargo is not systematized. This shows that, in the face of increasingly fierce external competition in the world market, the economy is weak and the attractiveness of investment has diminished. The most relevant factors to decide on a transportation mode are cost, time, and safety level; which implies deciding on which transportation mode, whether road or rail, incurs more or less cost and time in the distribution of goods, which sometimes is complicated to know exactly the price and time of transportation, leading to uncertainty in decision making to choose the most appropriate mode of transportation. 
The objective of this research is to study the transportation costs of land routes between rail and road modes, as a comparative in the distribution of cargo goods in general for the optimization of mobility in Mexico.

Currently, the means of transportation are becoming a key point in the handling of goods in international trade, since it depends on them that the goods arrive in time and form to their destinations. In order to face the challenges demanded by globalization in the production-distribution-consumption chain; transportation has a very important role, being this a trigger for Mexico's communications infrastructure that constitutes one of the most effective elements to boost internal economic development (Secretaria de Comunicaciones y Transportes, 2015).

For this reason, it is necessary to look for new transportation alternatives, and cargo companies that provide more efficient services with higher quality to move goods from one place to another, as well as reducing transportation costs through rail transportation (Secretaria de Comunicaciones y Transportes, 2015).

For this reason, the design of a transportation model for specific yard-to-yard routes is proposed to identify the most optimal mode of transportation for the mobilization of general cargo goods and its cost. This model seeks to contribute to improve the distribution processes in the commercialization of goods, which will be reflected in a more assertive decision making and, in general, in a more efficient and effective logistics operation.

\section{Logistics and transportation}

In marketing management, Ballou (2005) defines logistics as "the process of efficiently planning, executing, and controlling the flow of raw materials, in-process inventories, finished goods, services, and related information from the point of origin to the point of consumption in order to meet customer needs." The APICS dictionary (2020) defines it as "In a supply chain management context, it is the subset of supply chain management that controls the shipment and storage of goods between, delivery and distribution."
Authors such as Bloch (2012) comments that, in the need for companies to be more competitive, logistics is an activity that adds value by transforming the business sector in their businesses. The Council of Logistics Management in 1988 modified its definition as 'Integrated Logistics Management', which defined it as the integrated part of the supply chain that plans, implements and controls the efficiency, effective flow and accumulation of goods, services and information concerning the node of origin to the node of consumption that satisfies the customer's needs.

For the case of transportation, Martinez (2009), describes two basic concepts, geographical space and movement, which is determined by displacement, exchange and relationship. Given this, it is considered in 1) its special structure and organization and transport networks, 2) the demand for transport services and 3) the systems that arise from the dialectic between networks-demand-space.

The sectorization of transportation in Mexico and the world will face unprecedented challenges caused by demographics, urbanization, pressure to significantly reduce greenhouse gas emissions in urban and rural areas, urban traffic congestion, aging and further deterioration of transportation infrastructure and equipment, and growth in terms of fuel demand.

The transportation infrastructure in Mexico, foreseen in the National Road Network, is composed of 780,511 kilometers, of which almost 175 thousand, that is, only $22.39 \%$, are paved; $10.04 \%$ are urban roads and linking infrastructure; so 527,345 are unpaved roads (Mexican Institute of Transportation, 2020). As for, "Railway infrastructure in Mexico is composed of: $17,360 \mathrm{~km}$ of concessioned main and secondary track, 4,474 $\mathrm{km}$ of auxiliary track (yards and slopes) and $1,555 \mathrm{~km}$ of private tracks, which together total 23,389 km of operated track." (Rail Transport Regulatory Agency, 2019). In the repositories of the University of Barcelona (2018), it is stated that "Supply chain professionals need to be clear about what logistics is. 
By this term we refer to the function that deals with planning, implementing and controlling the efficient and effective flow of services, information and goods between the point of origin and the point of consumption, ensuring that, both the transportation and storage functions contribute to meeting customer requirements."

\section{Methodology}

For the methodology used in this research, it was based on 4 stages, which are:

\section{Research perspective}

The present research is based on the mixed approach, taking the approach of Hernández, Fernández and Baptista (2010), "quantitative and qualitative data are collected, analyzed and linked in the same study or a series of investigations to respond to an approach. The goal of mixed research is not to replace quantitative research or qualitative research, but to use the strengths of both types of inquiry, combining them and trying to minimize their potential weaknesses". In this research, information is taken on the routes with transit in the movement of national goods from yard to yard, the cargo that is most distributed regardless of the direction of origin and destination. This allows performing the different statistical tests on the dependent and independent variables such as rail and road transportation, cost, routes with distances greater than $500 \mathrm{~km}$, so that later deductions can be made on their behavior (Jiménez, 2016). The most used rail transport routes are analyzed for the movement of goods and to reduce costs mediate the use of rail transport in Mexico, comparing the distances between road routes and rail routes, general cargo goods which is merchandise that can be loaded in both means of transport, as well as using a full load.

This research intends to prove the possible answer to the problem posed from a non-experimental design in which the phenomena are identified as they occur in the natural environment so that they can be analyzed later; a transversal field study of descriptive-interpretative scope was applied, which is understood as a strategy or plan where we obtain information at a certain moment, through direct observation at the real moment in order to be able to interpret the facts.
A transversal descriptive exploratory design is handled, since the routes are described and in a period of time to calculate the costs of both transports and to be able to make a comparison of the rail and road transport in the country, with the similarity of the mobilization of two cargo containers in general. Because it is investigated how rail transport has behaved in Mexico to determine which are the routes and costs for the transfer of goods.

\section{Analysis and obtaining of information}

To obtain the information in this research, secondary sources were used that do not intend to associate the results, such as the material collected from the Internet, scientific journals of national and international circulation, electronic consultation of statistical data prepared by international organizations, as well as printed material (specialized books).

For this reason, a content analysis is generated in the collection of the information of the railway companies on the routes that transit merchandise with distances greater than five hundred kilometers and their general cargo merchandise that they distribute. In this research, a survey is not applied since the population is very small and only consists of nine railway companies that administer the railway system in Mexico, for which a census was applied.

In the collection and reading process phase, the selection of the bibliography or documentary references related to the research topic was carried out, at the same time an exploratory reading was implemented.

Afterwards, an analytical and critical reading was carried out to analyze and interpret the selected information, in order to identify and order the points that were related to the statement of the problem and that make up the support in the theoretical framework. Since the information on the routes and the merchandise is available, a matrix was generated, the restrictions were generated and the information was entered in the computational statistical program to carry out the execution of the data and make the inference of these variables. 


\section{Calculation of fees}

Having the information, the origins and destinations of the routes with the most traffic or movement of goods were determined; 8 routes of origin were identified, namely: 1 Manzanillo, 2 Lázaro Cárdenas, 3 Veracruz, 4 Nuevo Laredo, 5 Mexicali, 6 Ciudad Juárez, 7 Salinas Cruz and 8 Tampico. These origin routes have 2 destinations each, Mexico City and Mexicali. In the case of the Mexicali origin route, it will only have one destination, Mexico City.

Through the railway company Ferromex, various data were obtained that helped determine costs, considering the presence of this railway company and the Single Rate of Cargo and Express (TUCE). The TUCE (Equation 1), is indicated as:

TUCE $=($ cont $) *\left[(\operatorname{tar} f)+\left(\frac{\operatorname{tar} v}{k m}\right) *(k m)\right]$

Where:

cont $=$ Number of containers

$\operatorname{tar} f=$ Fixed rate per container

$\operatorname{tar} v=$ Variable rate per container

$\mathrm{km}=$ Kilometers of the route

For the application of the TUCE, it is important to know the distance between the nodes; therefore, two estimates will be applied in its calculation. For distances less than or equal to 500 kilometers, the rate to be applied corresponds to considering $\$ 4,233.79$ as a fixed rate, plus the variable rate $(\$ 14.2902)$ multiplied by 500 kilometers.

$\$ 11,378.89=4233.79+(14.2902 * 500)$

This fee is uniform per container for all routes whose distance does not exceed 500 kilometers.

For the case of two containers whose distance to be traveled is from 0 to 500 kilometers, the calculation would be:

$2 * \$ 11,378.89=\$ 22,757.78$

For the case where the rate exceeds 500 kilometers, equation 1 is applied, which applies the variable rate to all kilometers and adds the fixed rate:

\section{$4233.79+(14.2902 *$ kilómetros recorridos $)$}

For example, when considering the route from Manzanillo to Mexico City, you have 960 kilometers; therefore, the rate to be applied would be:

$4233.79+(14.2902 * 960)=17,952.38$

This model is known as a transportation model, since many of the applications are based on optimizing the transportation of goods and many others are based on the scheduling of the production of a specific product. In general, the transportation problem lies in stipulating the routes to be used and the quantities to be distributed in order to obtain a minimum transportation cost between the nodes of origin and the nodes of destination, given the demand that allows to know the transportation costs between each of these routes (Medina, 2007).

\section{Transportation Model}

The transportation model is an exclusive linear programming problem, as detailed by Soler et. al. (2007), its application is used in the planning of distributing goods and services with the supply nodes that go to different destinations. The objective of this model is to minimize the transportation costs of goods from some origin to various destinations, given the supply at those origins, which must satisfy the destinations that demand the products. It is necessary to identify certain information to determine the program, such as: the points of origin, the destination points, the distances, the routes with greater movement of goods, the load. Once the problem data have been identified, the model can be proposed and programmed. When posing the problem, different elements must be identified, such as the decision variable, objective function, linear restrictions and non-negativity restrictions; therefore, a demander can receive a certain quantity requested from one or several suppliers. To calculate the transportation tariff, a formula is used that in general terms has its variables known, which is:

$T=C F+C V(D)$

Where:

$C F=$ fixed costs

$C V=$ variable costs

$D=$ the distance to be traveled for the quoted trip. 
The first variable of fixed cost is determined by the sum of the total cost applied to the salaries and wages of directors and managers, insurance, taxes, duties and expenses of domestic services used in the company, among others. The variable cost is determined by the sum of all expenses incurred during the application of transportation, such as fuel, maintenance, tires, expenses incurred in transportation, payment of operators, and so on. For the distance it is a function of the route to be transported, being variable the number in each of the routes found between the origins and destinations according to the matrix created.

\section{Simplex method}

For Taha (2017), this method is analytical for the solution of problems in linear programming, which allows solving complex models and results with a graphical method that has no restriction with the variables that are occupied. While for Hiller (2015), it is an iterative method that improves the solution of the problem in steps; there is a mathematical reason to improve the method consisting of mobilizing the vertex of a polyhedron with a neighboring vertex so that it increases or decreases according to the determined objective function (minimize or maximize) and that this reason has a finite solution to obtain a solution. To potentiate this method, it is necessary to deepen the analysis of the matrix form in its notation that represents the linear programming problem.

The representation of the matrix form in the simplex method assumes that the problem fits the linear programming modeling, which is established with the objective function that allows optimizing the transportation cost to obtain the general result matrix (Taha,2017).

As commented by López (2019), a special network problem in linear programming is the transportation or distribution problem based on the need to take a unit from a specific point named origin or source to another specific point called destination.

He agrees that the solution procedure can be carried out by means of common linear programming with the simplex method, but, although its solution is not sensible, it turns out to be profitable for its modeling.
For the application of the model it is assumed that there are $m$ origins and $n$ destinations. Let $a_{i}$ be the arrangement of the number of units offered at each origin $i=(i=1$, $i=2, \ldots, m)$ and let $b_{j}$ be the requirement of the number of units at destination $j=(j=1, j=2, \ldots$, $n)$. The cost of transportation per unit on the route is determined by $C_{i j}(i, j)$ which adjoins origin $i$ and destination $j$. The objective is to determine the number of units transported from origin $i$ to destination $j$ in such a way as to minimize the total transportation costs.

Let $X_{i j}$ be the number of units transported from origin $i$ to destination $j$; then, the representation of the transportation model applied in the linear programming model is:

Minimize:

$\sum_{i=1}^{m} \sum_{j=1}^{n} c_{i j} x_{i j} \rightarrow$ Objective Function

Subject to:

$\sum_{\substack{j=1 \\ m}}^{n} x_{i j}=a_{i}, \quad i=1,2, \ldots, m \rightarrow$ offer
$\sum_{i=1}^{m} x_{i j}=b_{j}, \quad j=1,2, \ldots, n \rightarrow$ Demand

With $x_{i j} \geq 0$ for all $i$ and for all $j$.

In the case of allocating the quantities of goods to each of the demanders, the quantity available is not applied as a restriction. That is, each of the suppliers can deliver all, some or none of the merchandise that satisfies the demand of the demanders or consumer markets (Taha, 1988).

The model described implies that the total supply $\sum_{i=1}^{m} a_{i}$ must be at least equal to the total demand $\sum_{j=1}^{n} b_{j}$. When total supply equals total demand, the resulting calculated formula is renamed the Equilibrium Transportation Model. In practice the model may not be in equilibrium, however, it can be balanced by adding a fictitious source, when demand is in its case greater than supply, or by adding a fictitious destination, if supply is in its case greater than demand (Taha, 1995). 
In this sense, the application of the Simplex Method relates the transportation costs of 2 containers of general cargo goods for the routes established between rail and road transportation in order to minimize the costs and thus obtain the route that represents the lowest cost to send the general cargo goods by any of the selected means of transportation.

\section{Results}

For the exercise of this research, we had the participation of freight transportation companies (names are omitted for confidentiality), which is intended to receive two containers of cargo in a warehouse in Mexico City and another in Mexicali, there are 8 origins that can send containers to Mexico City, but only 7 of these proposed origins can send to the city of Mexicali. It is known that for rail transport more than two containers can be transported, but the calculation will be established with only 2 , since road transport is by standardization the only thing allowed per motor unit that can be transported. In the case of the calculation of costs for rail transport, the specific routes can be taken and the matrix for the 16 routes can be generated (Table 1).

\begin{tabular}{|c|c|c|}
\hline Route & $\mathbf{K m}$ & Total cost \\
\hline MZ-CDMX & 960 & $\$ 35,904.76$ \\
\hline LC- CDMX & 863 & $\$ 33,132.47$ \\
\hline VER- CDMX & 450 & $\$ 22,757.78$ \\
\hline NL- CDMX & 1122 & $\$ 40,526.21$ \\
\hline MXI- CDMX & 2584 & $\$ 82,319.33$ \\
\hline CJ- CDMX & 1813 & $\$ 60,289.56$ \\
\hline SC- CDMX & 854 & $\$ 32,875.24$ \\
\hline TAM-CDMX & 406 & $\$ 22,757.78$ \\
\hline MZ-MXI & 2235 & $\$ 72,344.77$ \\
\hline LC-MXI & 2519 & $\$ 80,461.61$ \\
\hline VER- MXI & 3105 & $\$ 97,209.72$ \\
\hline NL- MXI & 3510 & $\$ 108,784.78$ \\
\hline MXI- MXI & 0 & $\$ 3,600$ \\
\hline CJ-MXI & 5126 & $\$ 154,970.71$ \\
\hline SC-MXI & 3496 & $\$ 108,384.66$ \\
\hline TAM-MXI & 2811 & $\$ 88,807.08$ \\
\hline
\end{tabular}

Table 1 Calculation of rail transportation costs Source: Own Elaboration with information obtained from calculations

Now, in order to obtain the road freight rates, a transportation company provided its rates, which, like those for rail transportation, are variable according to various factors; the company is in charge of calculating the cost, considering various concepts, including the risk or dangerousness of the cargo route.
Table 2 shows the calculation of road transportation costs stipulated by the company for the same routes. By having the same supply-demand of two containers for each route, it was decided to restrict the amount of money available for each route, this restriction is due to the fact that the road transport can only drag a maximum of two containers due to the specification that are implemented in the NOM-012-SCT-2008 standard.

\begin{tabular}{|l|r|r|}
\hline Route & $(\mathbf{K m})$ & \multicolumn{1}{c|}{ Total cost } \\
\hline MZ-CDMX & 960 & $\$ 25,299.56$ \\
\hline LC- CDMX & 863 & $\$ 26,687.00$ \\
\hline VER- CDMX & 450 & $\$ 17,751.30$ \\
\hline NL- CDMX & 1121.7 & $\$ 69,038.55$ \\
\hline MXI- CDMX & 2584 & $\$ 112,784.88$ \\
\hline CJ- CDMX & 1813.2 & $\$ 56,066.08$ \\
\hline SC- CDMX & 854 & $\$ 18,940.46$ \\
\hline TAM-CDMX & 406 & $\$ 22,431.36$ \\
\hline MZ-MXI & 2235.1 & $\$ 102,354.58$ \\
\hline LC- MXI & 2519 & $\$ 67,723.52$ \\
\hline VER- MXI & 3105 & $\$ 83,710.80$ \\
\hline NL- MXI & 3510 & $\$ 68,117.40$ \\
\hline MXI- MXI & 0 & $\$ 3,600$ \\
\hline CJ MXI & 5126 & $\$ 31,852.08$ \\
\hline SC- MXIC & 3496 & $\$ 111,802.08$ \\
\hline TAM-MXI & 2811 & $\$ 89,895.78$ \\
\hline
\end{tabular}

Table 2 Calculation of road transportation costs Source: Own Elaboration with information obtained from calculations

Once the information on distances, proposed routes and restrictions were available, the cost matrix was created and executed in the computational language for Linear Programming, with the objective function and its supply and demand restrictions.

Finally, the data obtained from the run are analyzed and a cost comparison is made between rail and road transportation to determine which is more viable to transport the cargo in general and thus optimize its cost.

The results of the mathematical model proposed for the solution of this practical case of optimization of transportation costs, shows the assigned value (activity of the variable) at zero for all variables; this is due to several factors such as:

The rail freight rate is variable according to the material to be transported, weight, number of containers and kilometers to be traveled; therefore, when any of these factors change, the rate changes. 
- $\quad$ The determination of the road freight cost is also variable and takes into account several factors such as mileage, toll booth payments, variable costs, fuel cost, maintenance cost, lubricant cost, among others.

Table 3 shows a comparison of the costs of the selected routes, indicating which is the optimal transport with the lowest cost between rail and road transport within the same route. This table was created with the results obtained in linear programming language, which allows us to identify which costs were minimized in the different routes.

\begin{tabular}{|l|r|r|r|r|}
\multicolumn{1}{c}{ Destination } & \multicolumn{2}{c|}{... to CDMX } & \multicolumn{2}{c|}{... to Mexicali } \\
\cline { 2 - 6 } \multicolumn{1}{c|}{ Origin } & Rail & \multicolumn{1}{l|}{ Road } & \multicolumn{1}{l|}{ Rail } & \multicolumn{1}{l|}{ Road } \\
\hline 1 Manzanillo & --- & 25299.56 & 72344.77 & -- \\
\hline 2 Lázaro Cárdenas & --- & 26687 & --- & 67723.52 \\
\hline 3 Veracruz & --- & 17751.3 & --- & 83710.8 \\
\hline 4 Nuevo Laredo & 40526.21 & --- & --- & 68117.4 \\
\hline 5 Mexicali & 82319.33 & --- & N/A & N/A \\
\hline 6 Ciudad Juárez & --- & 56066.08 & --- & 31852.08 \\
\hline 7 Salinas Cruz & --- & 18940.46 & 108384.66 & --- \\
\hline 8 Tampico & --- & 22431.36 & 88807.08 & --- \\
\hline
\end{tabular}

Table 3 Results of minimum costs by route between rail and road transportation

Source: Own Elaboration

\section{Conclusions}

This research is considered as a contribution to the empirical analysis of rail and road transportation of general cargo goods in Mexico, based on the comparison of the distribution of general cargo goods, in order to lay the groundwork for a proposal to optimize transportation and its mobilization in Mexico; which can be concluded that:

1. By applying the cost optimization methodology of the transportation model, in rail and road modes, it is determined that most of the selected routes, road transport is more economical (for 2 containers), since, on the other hand, economies of scale in greater movement of containers, rail transport is more economical.
2. It is estimated that the costs of distribution of cargo goods in general on the busiest routes in Mexico in relation to time and distance are lower for rail transport than for road transport, particularly for the routes Nuevo Laredo - Mexico City, Mexicali - Mexico City, Salina Cruz - Mexicali, Manzanillo Mexicali and Tamaulipas - Mexicali; Therefore, in relation to time and distance, they are greater for rail transport than for road transport, applicable to the following routes: Manzanillo - Mexico City, Lázaro Cárdenas - Mexico City, Veracruz Mexico City, Ciudad Juárez - Mexico City, Salina Cruz - Mexico City, Tampico - Mexico City, Lázaro Cárdenas - Mexicali, Veracruz Mexicali, Nuevo Laredo - Mexicali, Ciudad Juárez - Mexicali, and Ciudad Juárez - Mexicali.

3. It is identified that for the railroad companies that, since there is a greater movement of merchandise by this means, they would have a greater benefit by reducing costs when sending their merchandise in scale by railroad transportation, trying to find the best way to become competitive both nationally and internationally.

4. Rail transport has more advantages in cargo capacity since the comparison was only made for 2 containers, which is the maximum that road transport can carry, and for it to be viable, the distances must be greater than $500 \mathrm{~km}$.

\section{References}

Agencia Reguladora del Transporte Ferroviario-Gobierno de México (2019). Publicado en su portal de internet: https:/www.gob.mx/artf/articulos/infraestructur a-ferroviaria-191183?idiom=es. Consultado el 16 de junio el 2021.

APICS. (2020). Association for Supply Chain Management.

Ballou, Ronald H. (2005) "Administración de la cadena de suministro", Pearson Education Inc 
Bloch, R. (2012). Aplicaciones Militares y civiles del concepto de logística. Instituto Tecnológico de Bs.As.(ITBA).

Ferrocarriles Nacionales Mexicanos. (2011). Renacimiento de lo ferrocariles mexicanos de carga.

Hernández Sampieri R., Fernández Collado C., Baptista Lucio P. (2010) Metodología de la investigación. Quinta Edición. Ed. Mc Graw Hill. México.

Hillier, F. (2015). Introducción a la investigación de operaciones, Mc Graw-Hill.

Instituto Mexicano del Transporte- Gobierno de México (2020). Publicación en su portal de internet: https://www.gob.mx/imt/acciones-yprogramas/red-nacional-de-caminos.

Consultado el 16 de junio el 2021.

Instituto Nacional de Estadística y Geografía. (2015). Balanza comercial de mercancías por países y zonas geográficas. Banco de Información Económica.

Jimenez Sánchez, J.E. (2016). Logística del autransporte de carga: Estrategias de gestión. Publicación Técnica No. 483. Instituto Mexicano del Transporte. Sanfandila, Querétaro. ISBN 0188-7297.

López, B. S. (junio de 2019). https://www.ingenieriaindustrialonline.com/inv estigacion-de-operaciones/problema-deltransporte-o-distribucion/.

LPI. (2020). Indice del Desempeño Logistico. Consultado el 17 de marzo del 2021.

Martínez Perdomo, Florián Rosa (2009). El sistema de transporte de carga en la Ciudad de México. Factores a considerar en el análisis del transporte de carga y la movilidad de mercancías. Territorios, (20-21),161174.[fecha de Consulta 16 de Junio de 2021]. ISSN: 0123-8418. Disponible en: https://www.redalyc.org/articulo.oa? $\mathrm{id}=357142$ 48008 Ramírez, S. M. (2013). BANCOMEXT. México: Bancomext.

Medina, L. (2007). Utilización del modelo de transporte para la asignación de trabajos a maquinas considerando prioridades.
Medina Ramírez, S. (2013). El transporte ferroviario en México. Revista Comercio Exterior. Vol. 63 No. 4, Julio y agosto, 2013. México. ISNN 0185-0601 pp. 7-13

Naumann, F. F. (2004). CIDAC e IMCO, Los retos de la competitividad en México. Una agenda de reformas inmediatas.

OMC. (2014). Informe sobre el comercio mundial. Factores que determinan el futuro del comercio. OMC.

Secretaria de Comunicaciones y Transportes. (15 de 02 de 2015). Secretaria de Comunicaciones y Transportes. Obtenido de Secretaria de Comunicaciones y Transportes: http://nats.sct.gob.mx

Soler, F., Molina, F., y Rojas, L. (2007). Álgebra y programación lineal. Bogotá, Colombia: Ecoe.

Taha, H. (2017). Investigación de Operaciones. 10ed Pearson Education. México.

Taha, Handy A. (1995). "Investigación de operaciones", Alfaomega, pp 11.

Universidad de Barcelona. (2018). Qué es logística y por qué se confunde con gestión de cadena de suministro. 